\title{
The Magma-Hydrothermal System at Mutnovsky Volcano, Kamchatka Peninsula, Russia
}

\author{
by John Eichelberger, Alexey Kiryukhin, and Adam Simon
}

doi:10.2204/iodp.sd.7.09.2009

\section{Introduction}

What is the relationship between the kinds of volcanoes that ring the Pacific plate and nearby hydrothermal systems? A typical geometry for stratovolcanoes and dome complexes is summit fumaroles and hydrothermal manifestations on and beyond their flanks. Analogous subsurface mineralization is porphyry copper deposits flanked by shallow $\mathrm{Cu}-\mathrm{As}-\mathrm{Au}$ acid-sulfate deposits and base metal veins. Possible reasons for this association are (1) upward and outward flow of magmatic gas and heat from the volcano's conduit and magma reservoir, mixing with meteoric water; (2) dikes extending from or feeding towards the volcano that extend laterally well beyond the surface edifice, heating a broad region; or (3) peripheral hot intrusions that are remnants of previous volcanic episodes, unrelated to current volcanism.

These hypotheses are testable through a Mutnovsky Scientific Drilling Project (MSDP) that was discussed in a workshop during the last week of September 2006 at a key example, the Mutnovsky Volcano of Kamchatka. Hypothesis

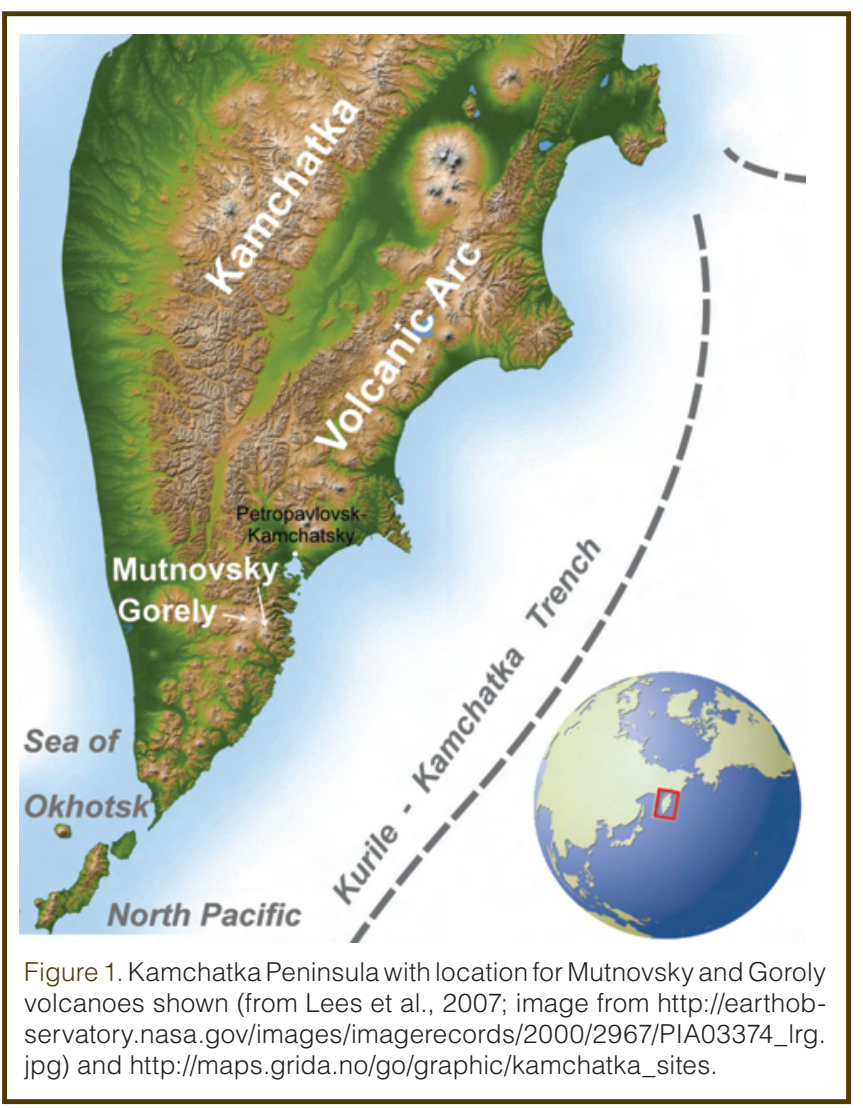

(1) was regarded as the most likely. It is also the most attractive since it could lead to a new understanding of the magma-hydrothermal connection and motivate global geothermal exploration of andesitic arc volcanoes.

\section{Geology and Volcanic Activity of Mutnovsky Volcano}

Mutnovsky Volcano on Russia's Kamchatka Peninsula (Fig. 1) is exemplary of associated hydrothermal and volcanic regimes. The volcano has gone through four stages spanning late Pleistocene through Holocene time. Each stage probably reflects the evolution of a small shallow magma reservoir, and the transition from one stage to the next has involved a shift of the eruptive center and perhaps the active reservoir by as much as $1 \mathrm{~km}$. All stages except for the current incompletely developed stage have produced magmas ranging from basalt to dacite (Selyangin, 1993). Mutnovsky IV is characterized by basaltic andesites. Mutnovsky III ended its eruptive cycle with a Holocene eruption of dacitic pyroclastic flows and emplacement of a dacite dome within its crater (Fig. 2). This crater has been enlarged by explosion, collapse, and/or erosion and is now occupied by a crater glacier, possibly the main recharge source of the hydrothermal system. The breach in Mutnovsky III crater, cut by a river, exposes a magnificent dike swarm (Fig. 3).

The crater of Mutnovsky III is the scene of intense fumarolic activity, modestly superheated and arranged in a ring, apparently defining the conduit margin of the late dacite dome. A powerful phreatic explosion in 2000 at the edge of the adjoined Mutnovsky IV crater reopened a large preexisting sub-crater. This event appears to have been caused

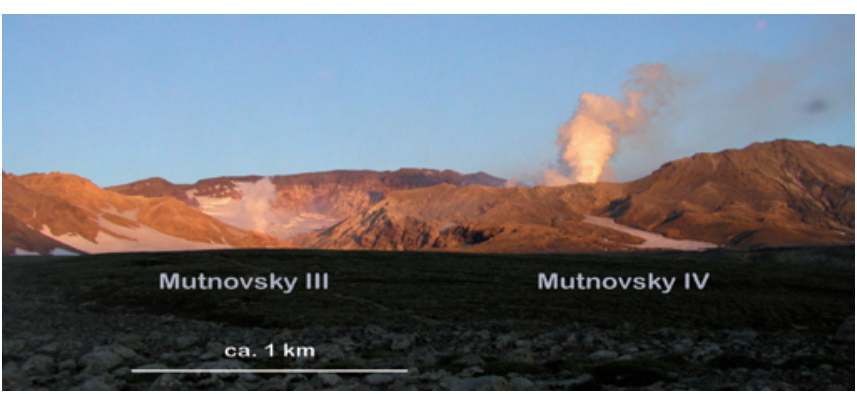

Figure 2. Mutnovsky Volcano from the west. The Crater Glacier and the hydrothermal plume of Mutnovsky III crater is visible through the breach formed by the Volcannaya River in Dangerous Ravine left of center. The larger plume from the Active Crater of Mutnovsky IV rises to the right. Width of the field of view is approximately $3 \mathrm{~km}$ (photo by J. Eichelberger). 
by a dike propagating upward and intersecting the hydrothermal system centered beneath Mutnovsky IV. A second power-ful explosion occurred in 2007, excavating a new sub-crater on the floor of the active crater of Mutnovsky IV.

Mutnovsky's geothermal field (Dachny) was discovered in 1960 and described in detail by Vakin et al. (1976). The active crater (Mutnovsky IV) has fumaroles as hot as $620^{\circ} \mathrm{C}$, emitting a continuous $\mathrm{SO}_{2}$-rich plume (92.8 wt\% steam, 3.3wt \% $\mathrm{CO}_{2}$, $2.9 \mathrm{wt} \% \mathrm{SO}_{2}, 0.6 \mathrm{wt} \% \mathrm{H}_{2} \mathrm{~S}$, $0.3 \mathrm{wt} \% \mathrm{HCl}, 0.1 \mathrm{wt} \% \mathrm{HF}$ and $\mathrm{H}_{2}$ ). Mutnovsky craters' com-

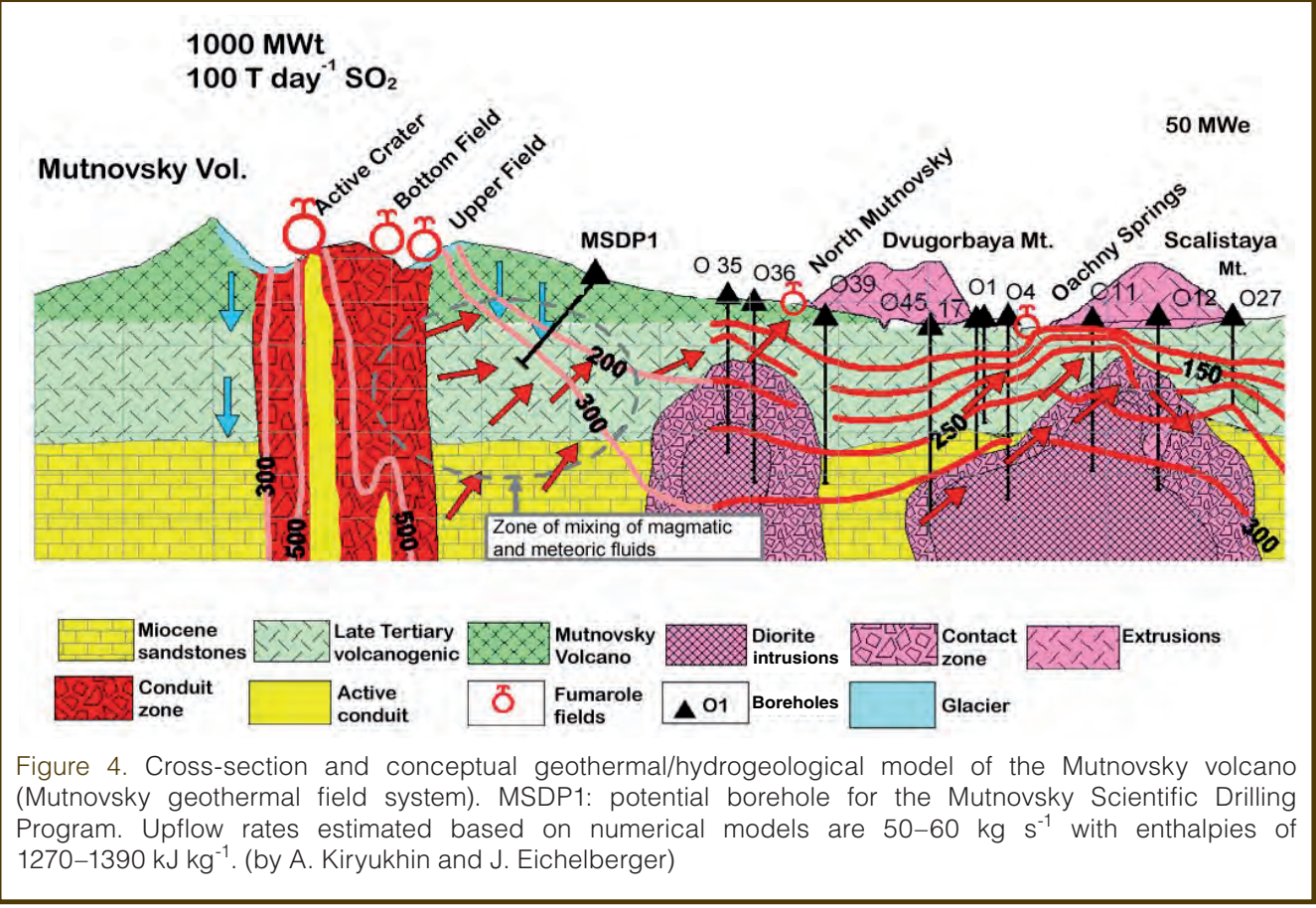
bined thermal $(>1000 \mathrm{MWt}$

with temperatures above $600^{\circ} \mathrm{C}$ ) and gas emission ( $100 \mathrm{~T} \mathrm{~d}^{-1} \mathrm{SO}_{2}$; Trukhin, 2003) imply shallow magma degassing (Wallace et al., 2003) and cooling at a rate on the order of $1 \mathrm{~m}^{3} \mathrm{~s}^{-1}$, a rate comparable to recent dome lava discharge rates of Mount St. Helens. This is exceptional for a volcano in repose and would seem to require robust magma convection within Mutnovsky's conduit. Moreover, the magmatic contribution is an underestimate because the hydrothermal system is apparently scrubbing gas output, an important issue in volcano monitoring. Scrubbing has given rise to an extraordinarily diverse population of Sulfolobus, a single-celled Archaea micro-organism. The opportunity to define the pressure and temperature limits of such microbiological activity as well as constrain its rate of evolution in a primordial environment is an exciting one, with implications for the origin of life on Earth and existence of life elsewhere in the solar system.

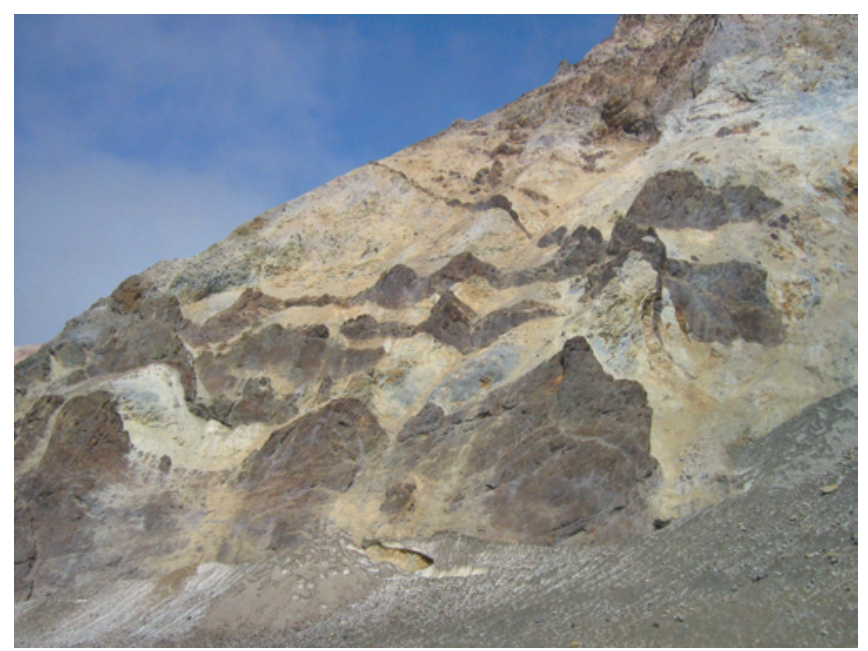

Figure 3. Dike swarm exposed in the wall of Mutnovsky III crater. Height of field of view is approximately $500 \mathrm{~m}$ (photo by J. Eichelberger).

Seismic modeling of Mutnovsky IV volcano's magma chamber, performed recently by Utkin et al. (2005), yielded the following estimations of chamber parameters: elevation-1.7 km (approximately $3 \mathrm{~km}$ depth), radius $1.5 \mathrm{~km}$, temperature $900^{\circ} \mathrm{C}-1250^{\circ} \mathrm{C}$. Heat content of the chamber and adjacent host rocks is estimated to be $3 \times 10^{19} \mathrm{~J}$. Fumaroles of the volcano are grouped as the Upper Field (UF) and Bottom Field (BF) of Mutnovsky III Crater and the Active Crater (AC) of Mutnovsky IV (Fig. 4).

In the laboratory, volcanic gases sampled with evacuated bottles were analyzed for $\mathrm{SO}_{2}$ and $\mathrm{H}_{2} \mathrm{~S}$. Condensates were analyzed for $\mathrm{HF}, \mathrm{HCl}$, and $\mathrm{HBr}$, and $\delta \mathrm{D}$ and $\delta^{18} \mathrm{O}$ values were determined in water from condensates. On a $\delta \mathrm{D}-\delta^{18} \mathrm{O}$ plot, all sampling points are close to a classic mixing line between magmatic water and local meteoric waters (Fig. 5). However, correlations between isotopic and chemical compositions

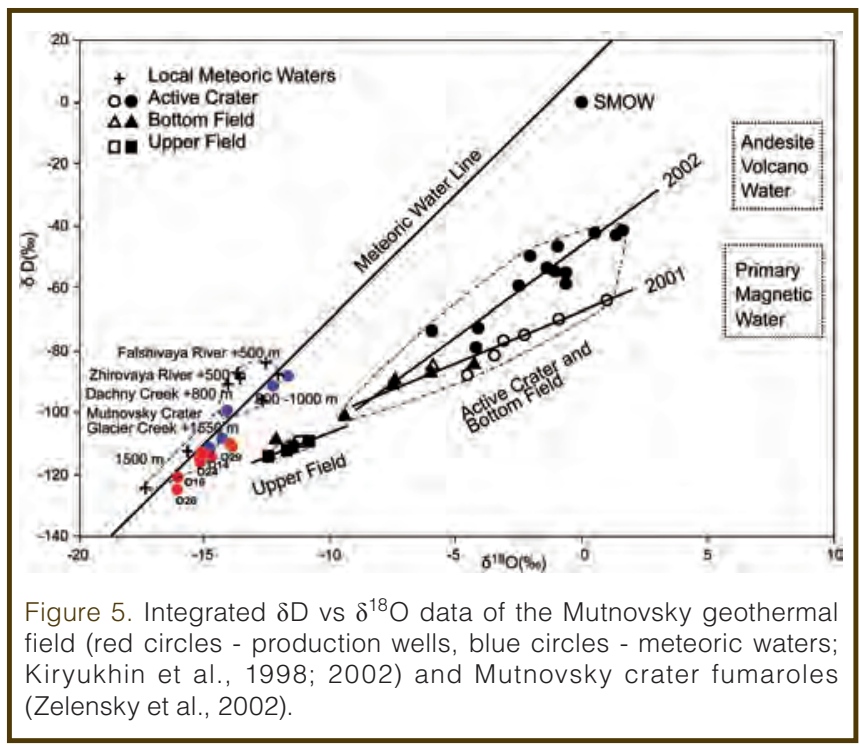


divide all fumaroles into two independent hydrothermal systems.

\section{The Mutnovsky Geothermal Field}

The main and the most powerful hydrothermal system discharges at the active crater and the BF. Gases of this system originate from mixing of magmatic $800^{\circ} \mathrm{C}$ fluid with low temperature $\left(100^{\circ} \mathrm{C}-150^{\circ} \mathrm{C}\right)$ hydrothermal steam. The source of the steam, according to its isotopic composition, may be meteoric waters from $900 \mathrm{~m}$ elevation. Another powerful hydrothermal system discharges as the upper fumarolic field (UF) with rather high temperature $\left(300^{\circ} \mathrm{C}\right)$ meteoric steam along with a very low content of acids. The steam mixes with cold meteoric water from 1500 m elevation, probablyfrom theadjacentcraterglacier.Complementary to the fumarole volatiles, an isotopic geochemistry study has been performed on the trace metals in the fumaroles. The solutions in the boilers have compositions that appear to be unique in the world due to extremely high contents of $\mathrm{Cl}, \mathrm{Cr}$, $\mathrm{Ni}, \mathrm{Co}$, Ti, V, and B (Bortnikova et al., 2007). These elements are extracted from magma and wall rocks by acid magmatic gases and then concentrated in zones of secondary boiling. Thus, a modern ore-forming zone exists in the region of brine formation.

Exploration work began in 1978, including delineation of surface manifestations, temperatures, soil gas surveys, resistivity surveys, T-gradient drilling, and drilling of eighty-nine exploration wells. Flow tests from production wells, conducted during the 1983-1987 time period, and modeling confirmed the potential for 50 MWe production. Hence, in 1999 a pilot 12 MWe power plant was put into operation, followed in 2002 by the Mutnovsky 50 MWe power plant, located about $8 \mathrm{~km}$ NNE of the Mutnovsky II Crater. Mutnovsky's geothermal power plant provides one-third of the nearby city of Petropavlovsk's electric power

\section{Conceptual Model of the Mutnovsky Magma-Hydrothermal System}

At Mutnovsky there are two strong arguments for a direct connection between geothermal production and active magma beneath the volcano. First, the main production zone in the Mutnovsky field is a dyke-like plane of high permeability that if projected towards the volcano intersects the active conduit at shallow depth. Second, there is a component of the producing fluid, defined in terms of $\mathrm{O}$ and $\mathrm{H}$ isotopic composition, for which the only known equivalent is the crater glacier. The glacier apparently acts as the main source of meteoric water recharge area for the fluids producing by exploitation wells. Meteoric recharge is accelerated by melting of the glacier due to high heat flows in the crater (Fig. 4).

Thermal input to the production zone may alternatively come from other magmatic bodies accumulated in the North
Mutnovsky volcano-tectonic zone. Some of the wells bottom in diorite intrusives that could represent a local heat source. It is not clear at present whether or not such bodies are (1) directly connected to the magmatic system of the active Mutnovsky volcano, (2) isolated remnants of magma intruded into the plane of hydro-magma-fracturing created by Mutnovsky volcano, or (3) as some have argued, much older intrusions related to a predecessor magmatic system unrelated to the current volcanic activity.

\section{Mutnovsky Scientific Drilling Project Workshop 2006}

Thirty-nine presenting scientists from Russia and six countries abroad, and many additional Russian participants for a total of about seventy, met in Petropavlovsk-Kamchatsky in September 2006 to consider scientific drilling at Mutnovsky. The meeting was held at the Institute for Volcanology and Seismology (IVS), Academy of Science of the Russian Far East.

The project concept, as introduced at the start of the meeting, was to drill and sample the magma-hydrothermal system at a point intermediate between the active craters and the geothermal production field, and to conduct hydraulic and chemical tests to assess their connectivity. With a system geometry characterized by lateral transition from magmatic vapor to dilute hydrothermal fluid at $<2 \mathrm{~km}$ depth, Mutnovsky is an attractive drilling target for understanding magma-hydrothermal interactions. The presentations and discussions included a number of past and current scientific drilling projects such as deepening of commercially drilled wells for scientific purposes. Further deliberations highlighted the research on several wells that have been drilled to depths exceeding $2000 \mathrm{~m}$ and to temperatures exceeding $300^{\circ} \mathrm{C}$.

Through the efforts of Russian scientists and the local development company, a large body of data already exists for the Mutnovsky system concerning fluid composition and conditions in the geothermal and volcanic systems. Some interesting pressure excursions have been associated with regional earthquakes, suggesting that the entire system may be a sensitive strainmeter. The three fumarole fields within the crater were defined as related through dilution of magmatic gas by meteoric water. Fumaroles depositing pyrite and arsenopyrite explain the remarkable chemistry (for example, the highest fumarolic $\mathrm{Cr}$ concentrations ever recorded). Mutnovsky's fumaroles are an epithermal ore-depositing system in action and have been termed "a unique natural chemical reactor" where thirty-five previously unknown hydrothermal minerals have been discovered. In counterpoint, some scientists view the volcano as a parasitic chimney on a more powerful and older Mutnovsky hydrothermal system. It should also be noted that the diverse microbiological population of extremophiles is an object of extensive international research. 
The workshop moved to the Mutnovsky Power Plant for two days of tours and discussions. The highlight of the meeting was the visit to Mutnovsky's craters. Under the leadership of Adam Simon, proposals for this pre-drilling phase of the project are being submitted to the U.S. National Science Foundation.

\section{Proposed Surface and Holes of Opportunity Investigations}

There are a number of surface investigations that will contribute to testing the single system hypothesis and help to guide and complement later dedicated scientific drilling. Thermal horizons, both magmatic and aqueous, have very low electrical resistivity in comparison with host rocks, and this resistivity provides a basis for using surface electromagnetic methods for their spatial definition. Magneto-telluric soundingscan be used to illuminate the magma-hydrothermal system by imaging conductivity distribution. Self-potential (SP) anomalies are directly related to subsurface heat and fluid movements; thus, SP mapping and modeling are strong tools to investigate the structure of a volcanic body and geothermal reservoir. In studying the Mutnovsky geothermal field, an SP mapping survey will be conducted widely in and around the Mutnovsky volcano.

In the area around the volcano there are no seismic stations. The nearest one is near Gorely Volcano at a distance of about $12 \mathrm{~km}$ to the northwest. In this situation, it is impossible to define seismic activity at Mutnovsky Volcano on a satisfactory level. One of the main tasks for future investigations in this area is acquisition of sufficient local seismic and geodetic observations in order to differentiate between production-caused and natural events and to assess the connectedness of the volcano and geothermal system (Fig. 6). If there is a hydraulic connection between the volcano and the geothermal field due to migration of magma, fluids, or both, the 4-D pattern of deformation and seismicity should detect it.

The project also proposes to establish and monitor a micro-gravity network and a continuous-gravity network at Mutnovsky, both of which will require GPS elevation control. The aim of the micro-gravity and ground deformation network is to quantify any sub-surface mass movements occurring as a result of magma movements, degassing episodes, hydrothermal activity and geothermal exploitation. In particular, microgravity data may be able to differentiate between deformation caused by migration of fluids and that caused by migration of magma.

Investigation of aqueous geochemistry of the system will be expanded so that analysis of surface and borehole fluids from the north flank of Mutnovsky and the production field span the same range of elements and isotopes as the thoroughly studied crater fumarole fields. These data will permit a much better assessment of Mutnovsky Volcano's contribution to the geothermal system than is possible now.

At this time there is just one well, where pressure monitoring with a capillary tubing system has been conducted from 1995 until September 2006. Intriguing pressure excursions have been recorded during and just prior to regional earthquakes. The hydrothermal system appears to function

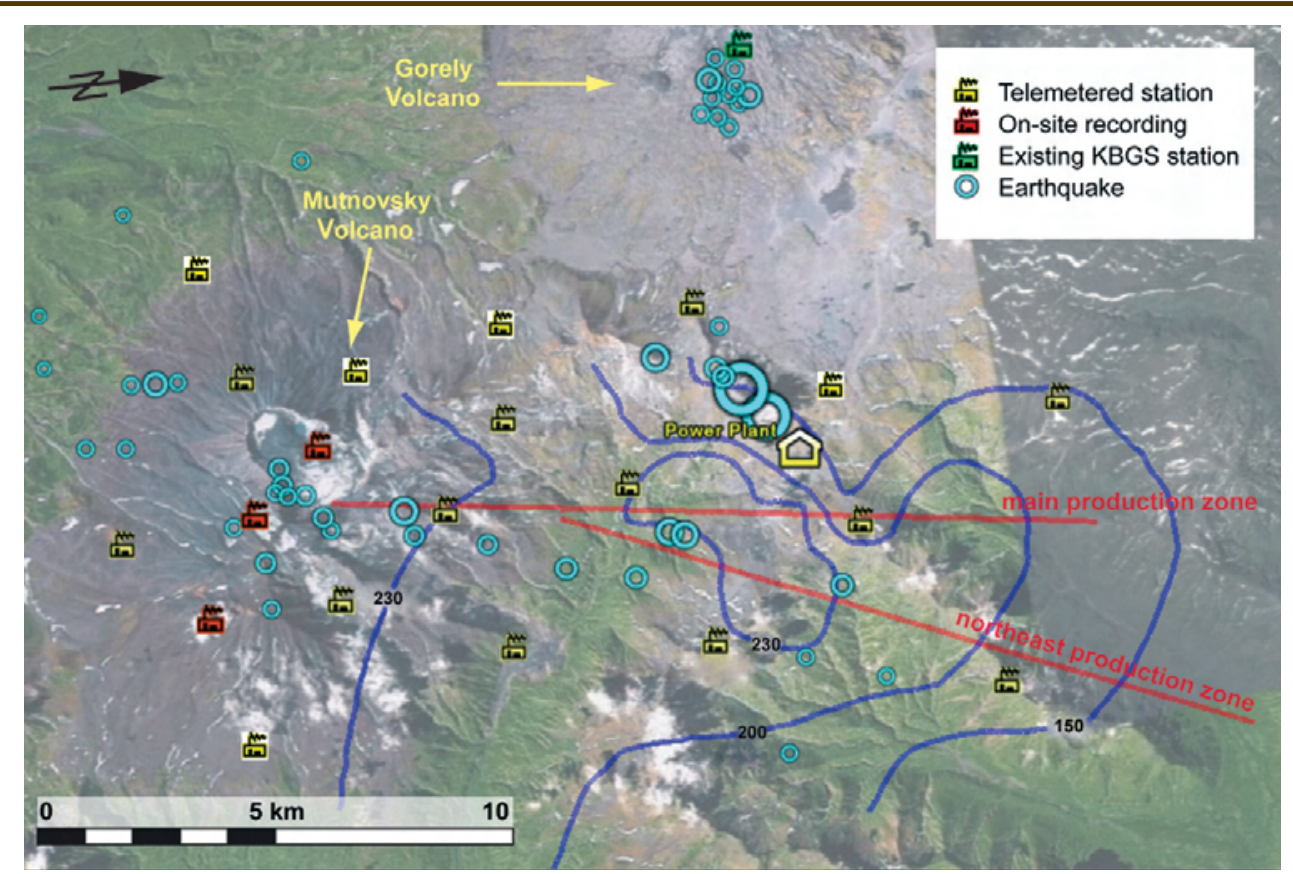

Figure 6. Proposed 20-station real-time seismic network at Mutnovsky Volcano and geothermal field. Earthquake epicenters (2001-2005) range in magnitude from $\mathrm{Ml}=1.8$ to 3.8. Red lines mark the high permeability planes where production wells are located. Blue lines mark geothermal contours at 250 mbsl (from Kiryukhin et al., 1998). Earthquake data are from the Kamchatka Branch of the Geophysical Service (KBGS), and the base photo is from Google Earth. as a sensitive strainmeter. This is consistent with many recent studies citing seismicity at volcanoes triggered by distant earthquakes, and speculating that earthquakes could trigger eruption. The utility of pressure sensors in multiple boreholes in assessing connectivity of the system is obvious, and it may even be possible to capture the fluid pressure signal in the near and far fields from phreatic explosions such as occurred in 2000 and 2007.

A considerable amount of core has already been acquired in the course of exploration and development of the Mutnovsky geothermal field. Core parameters are planned to be measured: density, porosity, gas permeability, 
pore space structure, microfracture network, sonic velocities, geomechanical characteristics (compression and tensile strength, elastic modulus), thermal and magnetic properties, and then interpreted according to the rocks' petrography. These subsurface properties will be used to create improved geophysical and surface deformation models. Chemical investigations of available core and surface samples will also reveal the internal geochemical stratigraphy of Mutnovsky Volcano. This work will involve unit-by-unit, high-quality geochemical analyses of drill core recovered by the project. The analyses of major and trace elements by X-ray fluorescence spectroscopy will also serve to identify hydrothermal alteration processes and the extent of alteration of the original magmas. These data will define the magma evolution of the Mutnovsky systems and its relationship to mineralization.

A goal of hydrothermal petrology of core will be to understand the permeability controls and chemical evolution of high-temperature, magmatically driven hydrothermal systems, mechanisms for focusing ore-formation, and energy use of Mutnovsky-type geothermal resources. The gas and heat output of the volcano can be viewed as providing a measure of the amount of magma undergoing decompression and cooling, respectively, per unit time. Taking the rough estimate of Mutnovsky's fumarolic $\mathrm{SO}_{2}$ output of $\sim 100 \mathrm{~T} \mathrm{~d}^{-1}$ and applying a value of solubility of $\mathrm{S}$ in basaltic andesite of $400 \mathrm{ppm}$ (Wallace et al., 2003) yields a result that about $1 \mathrm{~m}^{3} \mathrm{~s}^{-1}$ of magma must be decompressed to maintain this discharge rate. Cooling this amount of magma would satisfy the 1000 MWe thermal budget as well. This is not insignificant, being equivalent to the rate of extrusion of dome lava in 2007 at Mount St. Helens volcano, yet Mutnovsky is not erupting. The only obvious explanation for this behavior is that magma is vigorously convecting within the conduit that is undergoing decompression, but the degassed and cooled magma is flowing back down the conduit rather than erupting. An ascent rate of $1 \mathrm{~cm} \mathrm{~s}^{-1}$, (equivalent to that commonly inferred for lava eruptions) over a cross-sectional conduit area of $10 \mathrm{~m} 2$ would supply the observed $\mathrm{SO}_{2}$ discharge. When combined with new data on geochemistry of Mutnovsky magma and melt volatiles as a function of time, coupled gas/heat/mass flux observations will provide an unprecedented definition of the source term for the Mutnovsky magma-hydrothermal system.

\section{Drilling Investigations}

If the hypothesis of a direct magma-hydrothermal connection at Mutnovsky is correct, then our objective will become to penetrate and sample the transition zone. Such a borehole will become a key observation midpoint and sample port in a $10-\mathrm{km}$-long fracture-hosted system, with active magma at one end and geothermal production at the other. The magmatic end will be monitored at the surface within Mutnovsky III and active craters, and the geothermal end will be monitored at depth through existing wells. In addition to obtaining direct information on the current chemical and physical state of the system, it will be possible to use timedependent behavior to determine the hydraulic characteristics of the entire system.

The plan for drilling will be developed in parallel with progress in the surface investigations; however, some aspects of drilling can be considered now. It seems clear that drilling should penetrate as far beneath the Mutnovsky edifice and as close to the active conduit as possible. The borehole will therefore need to be directionally drilled. Its path should take it across the projection of the plane of geothermal production. The science team will continue discussions with the local geothermal company concerning the extent to which geothermal and scientific objectives can be combined and hence costs shared (for example, whether this could be a geothermal well that will be deepened for the scientific objectives). An important question is how close the well or wells can be sited to the volcano. If drilling conditions are favorable and data indicate that the active conduit is within reach, a subsequent stage of the project will be proposed aimed at intersecting, quenching at depth, and sampling magma. This is an objective embraced by the decadal white paper of ICDP (Harms et al, 2007) and would provide an unprecedented "ground truth" in volcanology, both in terms of the internal structure and conditions of volcanoes and the state and composition of unerupted magma. It will also be envisaged that MSDP will support continuation of the International Volcanological Field School based on Mutnovsky and founded in 2003 by the Kamchatka State University and University of Alaska Fairbanks.

\section{Summary}

The MSDP proposes a comprehensive geophysical and geochemical research program with stages wherein drilling will play an increasingly important role. Immediate priorities are magneto-telluric, seismic, geodetic, and gravity surveys to define the extent and behavior of the magma-hydrothermal system. The geothermal development company is currently drilling new 2000-m wells. This firm and the scientific drilling consortium formed at the workshop have agreed to collaborate in order to maximize scientific gain from drilled wells.

Based on results from this first phase, MSDP will drill a more proximal portion of the system that is hotter and more enriched in magmatic components than subsurface fluids previously sampled. Physical properties measurements on core will be used to refine initial geophysical models, particularly rheological properties relevant to inversion of measured surface displacements. Tracer and hydraulic tests will be used to assess overall connectivity of the system, from crater to production zone. Natural events, the numerous strong regional earthquakes and occasional eruptions, will also provide pressure perturbation tests. Finally, if feasibility can be demonstrated, we hope that the project will attempt to 
penetrate Mutnovsky's active conduit. The goal of reaching magma in a decadal time frame is one endorsed by the International Continental Scientific Drilling Program White Paper (Harms et al., 2007).

We anticipate important results in the following areas:

1. The relationship of hydrothermal activity to active volcanism, with implications for future geothermal exploration of circum-Pacific and other supra-subduction zone volcanoes.

2. The relationship of active ore deposition to fluid regimes, transitioning from high-temperature acid magmatic to moderate-temperature neutral hydrothermal.

3 . The extent and evolution of life in a sulfur-rich environment spanning a large temperature and pressure range

4. New constraints on the volatile budget of arc volcanoes; in particular, an assessment of subsurface "losses" to hydrothermal systems relevant to use of $\mathrm{SO}_{2}$ emission as a monitoring and eruption-predictive tool.

5. The deep structure of arc volcanoes and the nature of unerupted magma.

6. Engagement of students from a number of countries in international, resource-oriented research.

\section{Acknowledgements}

We thank the ICDP, IVS, UAFGI, Geotherm JSC, and SUE Kamchatskburgeotermia for their generous support. We also thank Uli Harms for persistence in extracting and patience in editing this report. Interested scientists are encouraged to write the authors of this report in order to be included in future communications and discussions.

\section{References}

Bortnikova, S.B., Sharapov, V.N., and Bessanova, E.P., 2007. Hydrogeochemical composition of springs at the Donnoe Fumarole Field, Mutnovsky Volcano (Southern Kamchatka) and problems of their relation with supercritical magmatic fluids. Dokl. Earth Sci., 413A(3):410-414, doi:10.1134/ S1028334X07030208.

Harms, U., Koeberl, C., and Zoback, M.D., 2007. Continental Scientific Drilling: A Decade of Progress and Challenges for the Future. Berlin (Springer), $366 \mathrm{pp}$.

Kiryukhin, A. V., Korneev, V.A., and Polyakov, A.Yu., 2006. On a possible relationship between strong earthquakes and anomalous pressure variations in a two-phase geothermal reservoir. Volcanology and Seismology Journal, 6:3-11 (in Russian).

Kiryukhin, A.V., Leonov, V.L., Slovtsov, I.B., Delemen, I.F., Puzankov, M.Yu., Polyakov, A.Yu., Ivanysko, G.O., Bataeva, O.P., and Zelenskii, M.E., 2005. Modeling the utilization of area Dachnyi of the Mutnovskii geothermal field in connection with the supply of heat-transfer agent to the $50 \mathrm{MW}$ Mutnovskii Geologic Power Station. Vulkanologiya $i$ Seismologiya, 5:19-44. Russian

Kiryukhin, A.V., Takahashi, M., Polyakov, A.Yu., Lesnykh, M.D., and Bataeva, O.P., 1998. Origin of water in the Mutnovsky geo- thermal field: an oxygen $\left({ }^{18} \mathrm{O}\right)$ and hydrogen (D) study. Volcanology and Seismology Journal, 4-5:54-62 (in Russian).

Lees, J.M., VanDecar, J., Gordeev, E., Ozerov, A., Brandon, M., Park, J., and Levin, V., 2007. Three-dimensional images of the Kamchatka-Pacific plate cusp. In Eichelberger, J., Gordeev, E., Kasahara, M., Izbekov, P., and Lees, J. (Eds.), Volcanism and Subduction: The Kamchatka Region, Geophysical Monograph Series 172, American Geophysical Union: 65-75.

Selyangin, O.B., 1993. New about Mutnovsky volcano. Vulkanologiya $i$ Seismologiya, 1:17-35 (in Russian).

Trukhin, Y.P., 2003. Geochemistry of the Active Geothermal Processes and Geotechnologies Applications. Moscow (Nauka Publ.), 376 pp. (in Russian).

Utkin, I.S., Fedotov, S.A., Delemen, I.F., and Utkina, L.I., 2005. Dynamics of the development of flowing magmatic chambers on Mutnovsko-Gorelovsky group of volcanoes, their thermal fields and underground heat capacity. Volcanology and Seismology Journal, 5:1-30 (in Russian).

Vakin, E.A., Kirsanov, I.T., and Kirsanova, T.P., 1976. Hot areas and thermal springs of the Mutnovskii volcanic region. Gidroterm. Sist. Term. Polya Kamchatski: 85-114 (in Russian).

Wallace, P.J., Carn, A.S., Rose, I.W., Bluth, J.S.G., and Gerlach, T., 2003. Integrating petrologic and remote sensing perspectives on magmatic volatiles and volcanic degassing. EOS, Trans. Am. Geophys. Union, 84(42):441-447, doi:10.1029/ $2003 \mathrm{E} 0420001$.

Zelensky, M.E., Ovsyannikov, A.A., Gavrilenko, G.M., and Senyukov, S.L., 2002. Eruption of Mutnovskii Volcano, Kamchatka, March 17, 2000. Volcanology and Seismology Journal, 6:25-28 (in Russian).

\section{Authors}

John Eichelberger, University of Alaska Fairbanks, Department of Geology and Geophysics, Reichardt Building, Alaska, U.S.A. [Current Address: Volcano Hazards Program, U.S. Geological Survey, 12201 Sunrise Valley Drive, MS 904, Reston, Va., 20192, U.S.A., e-mail: jeichelberger@usgs.gov.] Alexey Kiryukhin, Institute of Volcanology and Seismology, 9 Piip Boulevard, Petropavlovsk-Kamchatsky, 683006, Russia.

Adam Simon, Department of Geoscience, University of Nevada-Las Vegas, 4505 South Maryland Parkway, Las Vegas, Nev., 89154-4010, U.S.A.

\section{Related Web Links}

http://kamchatka.icdp-online.org

http://earthobservatory.nasa.gov/images/imagerecords/ 2000/2967/PIA03374_lrg.jpg

http://maps.grida.no/go/graphic/kamcatka_sites

\section{Photo Credits}

Figs. 2 and 3: J. Eichelberger 